\title{
Anti-inflammatory activity and identification of the Verbena litoralis Kunth crude extract constituents
}

\author{
Rachel de Lima ${ }^{1 *}$, Juliana Calil Brondani®1, Rafaela Castro Dornelles², Cibele Lima Lhamas ${ }^{3}$, \\ Henrique Faccin ${ }^{4}$, Carine Viana Silva ${ }^{1}$, Sérgio Luiz Dalmora ${ }^{1}$, Melânia Palermo Manfron ${ }^{1}$
}

${ }^{1}$ Post-Graduate Program in Pharmaceutical Sciences, Federal University of Santa Maria, Santa Maria, RS, Brazil, ${ }^{2}$ PostGraduate Program in Pharmacology, Federal University of Santa Maria, Santa Maria, RS, Brazil, ${ }^{3}$ Veterinary Hospital, Federal University of Santa Maria, Santa Maria, RS, Brazil, ${ }^{4}$ Chemistry Department, Federal University of Santa Maria, Santa Maria, RS, Brazil

\begin{abstract}
Verbena litoralis is a plant popularly known as "gervãozinho-do-campo" in Portuguese. It is traditionally used for stomach, liver and gallbladder problems, and as an anti-inflammatory and anthelmintic. The goal of this study was to determine the chemical composition of the crude extract obtained from the aerial parts of $V$. litoralis by Ultra High Performance Liquid chromatography coupled with Mass Spectrometry in Tandem (UHPLC-MS/MS); assess the anti-inflammatory activity of ethyl acetate fraction and of crude extract; and verify liver, kidney and pancreas damage. In this study, the chemical composition of the extract was identified via UHPLC/MS/MS, assessing the anti-inflammatory activity of the crude extract and the acetate fraction in an induction model of the granulomatous tissue, as well as given liver, kidney and pancreas damage markers. Chlorogenic acid, luteolin, caffeic acid, apigenin, p-coumaric acid, vanillic acid, ferulic acid and quercetin were quantified in the extract. After the seven-day treatment, the granuloma of the animals treated with the plant extract and fraction presented values very close to the positive control (nimesulide). The $V$. litoralis crude extract and ethyl acetate fraction show antiinflammatory activity similar to the nimesulide without evidence of liver, kidney and pancreas damage, which attributes the plant's pharmacological action to the flavonoids found.
\end{abstract}

Keywords: Verbena litoralis. UHPLC/MS. Flavonoids. Anti-inflammatory.

\section{INTRODUCTION}

Vegetables produce a wide variety of metabolites and are considered the oldest source of medicine for men. As potential sources of natural bioactive and antioxidant compounds, they have been investigated for their characteristics and effects on health (Brandão et al., 2010; Ghasemzadeh, Ghasemzadeh, 2011).

Verbena litoralis is a species of the Verbenaceae family, which occurs in tropical and subtropical regions, mainly in temperate regions of the Southern Hemisphere and, to a lesser extent, in temperate regions of the Northern Hemisphere (Barroso, 2004; Souza, Lorenzi, 2005).

This plant, commonly known as "gervãozinho-docampo" or "erva-de-pai-caetano" in Portuguese, is used

\footnotetext{
*Correspondence: R. Lima. Departamento de Farmácia Industrial, Faculdade de Farmácia, Universidade Federal de Santa Maria. Avenida Roraima, $\mathrm{n}^{\circ}$ 1000, Prédio 26, sala 1107, Bairro Camobi, Santa Maria, RS CEP 97105-900, Brasil. Telefone: (55) 98128-5718. E-mail: rachelzinhadelima@yahoo.com.br
}

ethnopharmacologically in popular medicine for stomach, liver, gallbladder, tonsillitis, bladder and kidney problems, as well as for uterus and ovary inflammations, spine affections, colic, and as an anthelmintic (Garlet, 2000; Marodin, 2000; Sebold, 2003). Studies with $V$. litoralis extracts show the presence of flavonoids, anthracenosides, cardioactives, hemolytic saponins, catechinic tannins and carotenoids in this plant. Volatile oils, coumarins and mucilages were present in a smaller quantity (Souza et al., 2005).

A drug's anti-inflammatory activity can be assessed through granuloma assay, which consists in the implementation of cotton pellets on the back of rats, causing the formation of a vascularized fibrous capsule, fibroblasts and infiltrating mononuclear cells. The drug's effect is evaluated by the size of the fibrous capsule developed. The smaller the capsule, the bigger the antiinflammatory effect produced by the tested drug (Bailey, Sturm, Lopez-Ramos, 1982; Dalmora, 1996). 
Flavonoids, which occur normally in plants, are water-soluble pigments that act as potent antioxidants able to eliminate hydroxyl radicals and superoxide anions (Dunne, 2009). Flavonoids are known to present antiinflammatory properties, an important characteristic, since the anti-inflammatory processes are involved in the development of cancer, so this confers to them a significant pharmacological importance (Seelinger et al., 2008).

This study's goal was to identify the chemical constituents of the crude extract, assess the crude extract and the acetate fraction anti-inflammatory activity of the aerial parts of $V$. litoralis via induction method of the granulomatous tissue, as well as assess if there was kidney, liver and pancreas damage by the determination of urea, creatinine, aspartate aminotransferase, alanine aminotransferase, amylase and lipase.

\section{MATERIAL AND METHODS}

\section{Botanic material collection and extract procurement}

Verbena litoralis was collected at the Federal University of Santa Maria (UFSM) campus (coordinates S 2942'56.1276" e W 53\%43'13.6632") in the City of Santa Maria, RS, Brazil. The plant was identified by Professor Ph.D. Thais Dorow of the Biology Department of UFSM. One exsiccate sample of the species was deposited in the Department of CCNE herbarium of the UFSM under the registry SMDB 13095.

\section{Extract preparation}

The crude extract of the aerial part pulverized was obtained by cold maceration with daily agitation and solvent renovation every 7 days for 30 days at room temperature. The solvent used was alcohol $70 \%$, which evaporated and the extract was freeze-dried and portioned by organic solvents of crescent polarity with n-hexane, chloroform, ethyl acetate and butanol originating the respective fractions (Simões et al., 2017).

\section{Polyphenol identification and quantification by UHPLC-ESI-MS/MS}

The analytical grade standards used with $95 \%$ purity were $(+)$-catechin, 3 -acetyl coumarin, 3,6-dihydroxyflavone, 4-hydroxycoumarin, 6-hydroxycoumarin, apigenin, chlorogenic acid, chrysin, fisetin, galangin, gallic acid, kaempferol, luteolin, myricetin, p-coumaric acid, quercetin, quercitrin, resveratrol, rosmarinic acid, rutin, trans-cinnamic acid and vanillic acid obtained from Sigma-Aldrich (St. Louis, MO, USA). Caffeic and ferulic acids were obtained from Fluka Analytical (Buchs, Switzerland).

Ultrapure water was obtained from a Milli-Q Synergy UV system (Merck Millipore, Darmstadt, Germany). Methanol and acetonitrile (LC-MS grade) were obtained from Panreac (Castellar del Vallès, Spain). Acetic acid was obtained from Sigma-Aldrich (St. Louis, MO, USA). Stock solutions of the standards (1000 $\left.\mathrm{mg} \mathrm{L}^{-1}\right)$ were prepared by the dissolution of appropriate amounts of substances in LC-MS grade methanol. All the solutions were stored in amber glass flasks at $-30{ }^{\circ} \mathrm{C}$ until used. Working solutions of the standards were prepared by the dilution of the stock solutions according to the desired concentrations (Faccin et al., 2016).

\section{UHPLC-ESI-MS/MS conditions}

Following Faccin et al. (2016), these separations were carried out on a UHPLC 1260 Infinity Binary system (Agilent, Santa Clara, CA, USA), which was able to operate at pressures up to 600 bar. A Zorbax SB-C18 Rapid Resolution HD column $(2.1 \times 50 \mathrm{~mm}, 1.8 \mu \mathrm{m}$, Agilent) was used at a temperature of $40^{\circ} \mathrm{C}$. The injection volume was $5 \mu \mathrm{L}$, and the injected aliquots were acidified to a final concentration of $0.1 \%$ acetic acid $(\mathrm{v} / \mathrm{v})$. The phenolic compounds were separated using a gradient elution composed of $0.1 \%$ acetic acid in water (A) and acetonitrile (B) as the mobile phase at a constant flow rate $\left(0.8 \mathrm{~mL} \mathrm{~min}^{-1}\right)$ according to the following elution program: $8.0 \%$ B (0.00-0.10 min); 8.0-25.8\% B (0.10-3.45 min); $25.8-54.0 \% \mathrm{~B}(3.45-6.90 \mathrm{~min}) ; 54.0-100.0 \% \mathrm{~B}$ (6.90-7.00 $\mathrm{min})$; and $100.0 \%$ B (7.00-9.00 min).

An electrospray ionization source (ESI) was used to ionize the chromatographic effluent generated up to $7.0 \mathrm{~min}$. The parameters for ESI were optimized to give the best response for the analytes especially for intensity and signal stability. The final optimized parameters were a gas flow of $11 \mathrm{~L} \mathrm{min-1,} \mathrm{a} \mathrm{nebulizer} \mathrm{of} 30 \mathrm{psi}$, a capillary voltage of $\pm 2.4 \mathrm{kV}$ and a gas temperature of $250{ }^{\circ} \mathrm{C}$, with nitrogen used as the drying gas. The compounds were subsequently analyzed in an Agilent 6430 Triple Quadrupole mass spectrometer, operating in the multiple reaction monitoring (MRM) mode with a resolution of $0.7 \mathrm{~m} / \mathrm{z}$ (FWHM). The quantification transitions were divided into three temporal segments of acquisition and the dwell time for each transition was optimized to $20 \mathrm{~ms}$. High purity nitrogen (99.999\%) obtained from Linde (Munich, Germany) was used as the gas for inducing collision (Faccin et al., 2016). 


\section{Sample analysis}

Around $0.06 \mathrm{~g}$ of the freeze-dried crude extract was re-suspended in $3 \mathrm{~mL}$ of methanol, sonicated until complete dissolution, and diluted with $12 \mathrm{~mL}$ of ultrapure water. Next, acetic acid was added to a final proportion of $0.1 \%(\mathrm{v} / \mathrm{v})$. Then, the extracts were filtered through hydrophilic PTFE membranes with a $0.2 \mu \mathrm{m}$ pore size.

The sample was submitted to a cleanup step using solid phase extraction (SPE). The Strata C18-E cartridges (Phenomenex, Torrance, USA), $500 \mathrm{mg}, 3 \mathrm{~mL}$, were conditioned with $6 \mathrm{~mL}$ of methanol: $0.2 \%$ acetic acid $(1: 1$, $\mathrm{v} / \mathrm{v})$ and equilibrated with $6 \mathrm{~mL}$ of $0.1 \%$ acetic acid (v/v) in water. A fixed volume of $2 \mathrm{~mL}$ of the obtained extracts with a final methanol:water:acetic acid composition of 20:80:0.1 (v/v) was percolated with a $2 \mathrm{~mL} \mathrm{~min}^{-1}$ flow rate, followed by washing with $2 \mathrm{~mL}$ of $0.1 \%$ acetic acid. Lastly, the cartridge was eluted with $2 \mathrm{~mL}$ of methanol.

Just before the chromatographic analysis, the eluate obtained from the SPE procedure was diluted in a $\mathrm{MeOH}: 0.2 \% \mathrm{CH}_{3} \mathrm{COOH}(1: 1, \mathrm{v} / \mathrm{v})$ solution.

\section{Anti-inflammatory activity}

\section{Animals}

Fasted male Wistar rats weighing between 180 and $200 \mathrm{~g}$, divided into 5 groups of 6 animals each were housed in air-conditioned, controlled conditions, with room temperature $22 \pm 2{ }^{\circ} \mathrm{C}$, relative humidity of $65 \%$, and artificial illumination $12 \mathrm{~h}$ per day. They were given free access to food and water. The assays were conducted in accordance with the national protection laws on animal welfare, as registered in the Ethical Committee of the Federal University of Santa Maria, number 009/2012.

\section{In vivo anti-inflammatory effect}

The anti-inflammatory effect of the formulations was assessed by the cotton pellet granuloma method, as described by Meier, Schuller and Desaulles (1975). The animals were divided into groups of six rats and anesthetized. Sterilized cotton dental roll pellets weighing $40 \mathrm{mg}$ each were implanted subcutaneously in four symmetrical positions at dorsal sites of each animal. $V$. litoralis crude extract and the acetate fraction, at a dose of $300 \mathrm{mg} / \mathrm{kg} /$ day, were divided into two administrations with a volume of $0.5 \mathrm{~mL}$ and given orally at intervals of 6 hours during 7 consecutive days. Control groups received a mixture of propylene glycol/water (20:80 $\mathrm{v} / \mathrm{v}$ ) and only water. As a reference, nimesulide, a nonsteroidal anti-inflammatory drug at a concentration of
$5 \mathrm{mg} / \mathrm{kg} /$ day was administered twice a day at intervals of 6 hours.

On the eighth day, the granulomas were removed, and the weights were determined after drying in an incubator at $60{ }^{\circ} \mathrm{C}$ for $24 \mathrm{~h}$. The difference between the final and initial weight of the granuloma was considered as the weight of the granulomatous tissue produced.

\section{Hematological assessment}

At the end of the treatment, approximately $5 \mathrm{~mL}$ of blood was collected in sterile bottles with and without anticoagulant ethylenediamine tetraacetic acid (EDTA). The blood samples for the hemogram were collected in bottles of $0.5 \mathrm{~mL}$ of blood containing $10 \mu \mathrm{L}$ of EDTA. This material was appropriately homogenized and refrigerated by a period no longer than two hours and then sent to the Laboratório de Análises Clínicas Veterinárias (LacVet) of UFSM to be processed. The serum was immediately separated from the blood portion and kept frozen for posterior use in biochemical assays.

A hematological assessment was performed as per the methods described by Schalm (1970), including global leukometry, hematimetry performed in electronic counter (BC-2800 Vet - Auto Hematology Analyzer, Mindray), and globular volume determination by the microhematocrit method. The cell differential count was determined after coloration with the hematological coloring (panoptical) of blood smear and microscopic revision. With the electronic counter help, total erythrocyte concentration $(/ \mu \mathrm{L})$, hemoglobin concentration $(\mathrm{g} / \mathrm{dL})$, RDW (\%), platelet concentration $(/ \mu \mathrm{L})$ and total leukocyte concentration $(/ \mu \mathrm{L})$ were determined. The mean corpuscular volume (MCV) and concentration of mean corpuscular hemoglobin (MCHC) values were calculated as per classic formulas recommended by Jain (1993). The total plasma proteins concentration ([PTref]) was obtained by manual refractometry (Instrutherm, Brazil).

\section{Biochemical evaluation}

A part of the collected blood samples was immediately separated to obtain the serum for later biochemical evaluation. These serum were stored at a temperature of $-20{ }^{\circ} \mathrm{C}$. Biochemical analysis of serum samples was performed to estimate the enzymes aspartate transaminase ([AST]) and alanine aminotransferase ([ALT]), the metabolic products urea ([urea]) and creatinine ([Crt]), as well as glucose ([glucose]) and cholesterol ([Cholesterol]) using commercial kits (Labtest ${ }^{\circledR}$ ) in a semi-automatic analyzer (Bioclin 
Mindray BA $88 \mathrm{~A}()$. This analyzer supports bi-chromatic tests for endpoint, fixed-time and kinetics methods. The principles of these determination methods are described below.

The $[\mathrm{AST}]$ determination is performed through catalyzation of a reversible reaction involved in aspartate deamination to form oxaloacetate. On the other hand, [ALT] mensuration is based on reversible catalyzation involved in alanine deamination to form pyruvate (Stockham, Scott, 2011). Both deamination methods are kinect and the results are express in units per liter (U/L).

[Crt] determination is performed via the kinect reaction of creatinine with alkaline picrate. Reaction measurement in the first minutes allows for [Crt] determination. The system is colorimetric by end-point reaction. Urea is determined through enzymatic hydrolysis by urease-producing ammonia and $\mathrm{CO}_{2}$. The ammonia formed reacts with 2-ketoglutarate and NADH in a reaction catalyzed by glutamate dehydrogenase causing oxidation of NADH to NAD. The consequent reduction of absorbance is proportional to the [urea] in the sample. The results of both products were expressed in milligrams per deciliter (mg/dL).

Glucose was determined based on the quantity of the hydrogen peroxide $\left(\mathrm{H}_{2} \mathrm{O}_{2}\right)$ formed in the catalyzed reaction by glucose oxidase with 4 -aminoantipyrine and phenol, under peroxidase catalyst action forming a red antipyrilquinonimine, which has a color intensity proportional to the [glucose] in the sample (Labtest Diagnóstica S.A.). The enzymatic system used in the reaction was measured by the colorimetric method of endpoint and the results are expressed in $\mathrm{mg} / \mathrm{dL}$.

For the total cholesterol dosage, the enzymatic colorimetric method based on the hydrolysis of cholesterol esters was used, forming free cholesterol and fatty acids. Free cholesterol is oxidized forming $\left(\mathrm{H}_{2} \mathrm{O}_{2}\right)$ and cholest4-en-one. In the presence of peroxidase and $\mathrm{H}_{2} \mathrm{O}_{2}$, phenol and 4-aminoantipyrine are oxidized forming, which has a maximum absorptivity in $500 \mathrm{~nm}$. The intensity of the color red formed in the final reaction is proportional to the [cholesterol] in the sample (Labtest Diagnóstica S.A.), results are expressed in $\mathrm{mg} / \mathrm{dL}$.

\section{Statistical analysis}

Results were expressed as mean \pm standard deviation. Statistical analysis was performed using one-way ANOVA followed by the Tukey Test $(p<0.05)$ using the GraphPad Prism software.

\section{RESULTS}

\section{Polyphenol identification and quantification by UHPLC-MS/MS}

With the Ultra High Efficiency Liquid Chromatography Coupled to Mass Spectrometry the Multiple reaction monitoring (MRM), chromatogram of calibration patterns in a $0.5 \mu \mathrm{g} / \mathrm{mL}$ in $\mathrm{MeOH} / \mathrm{CH}_{3} \mathrm{COOH}$ a $0.2 \%(1: 1, \mathrm{v} / \mathrm{v})$ concentration and Multiple reaction monitoring (MRM) chromatogram of the $V$. litoralis crude extract $(0.4 \%, \mathrm{~m} / \mathrm{v})$ were obtained (Figure 1$)$.

According to the results presented in Table I, the predominant phenolic compound was chlorogenic acid at a concentration of $1484.5 \pm 24.2 \mu \mathrm{g} / \mathrm{g}$, followed by luteolin $(177.7 \pm 4.7 \mu \mathrm{g} / \mathrm{g})$, caffeic acid $(41.8 \pm 2.9 \mu \mathrm{g} / \mathrm{g})$, apigenin $(37.9 \pm 0.8 \mu \mathrm{g} / \mathrm{g}), p$-coumaric acid $(33.1 \pm 0.4 \mu \mathrm{g} / \mathrm{g})$, vanillic acid $(18.1 \pm 3.0 \mu \mathrm{g} / \mathrm{g})$ and ferulic acid $(10.7 \pm 0.6 \mu \mathrm{g} / \mathrm{g})$.

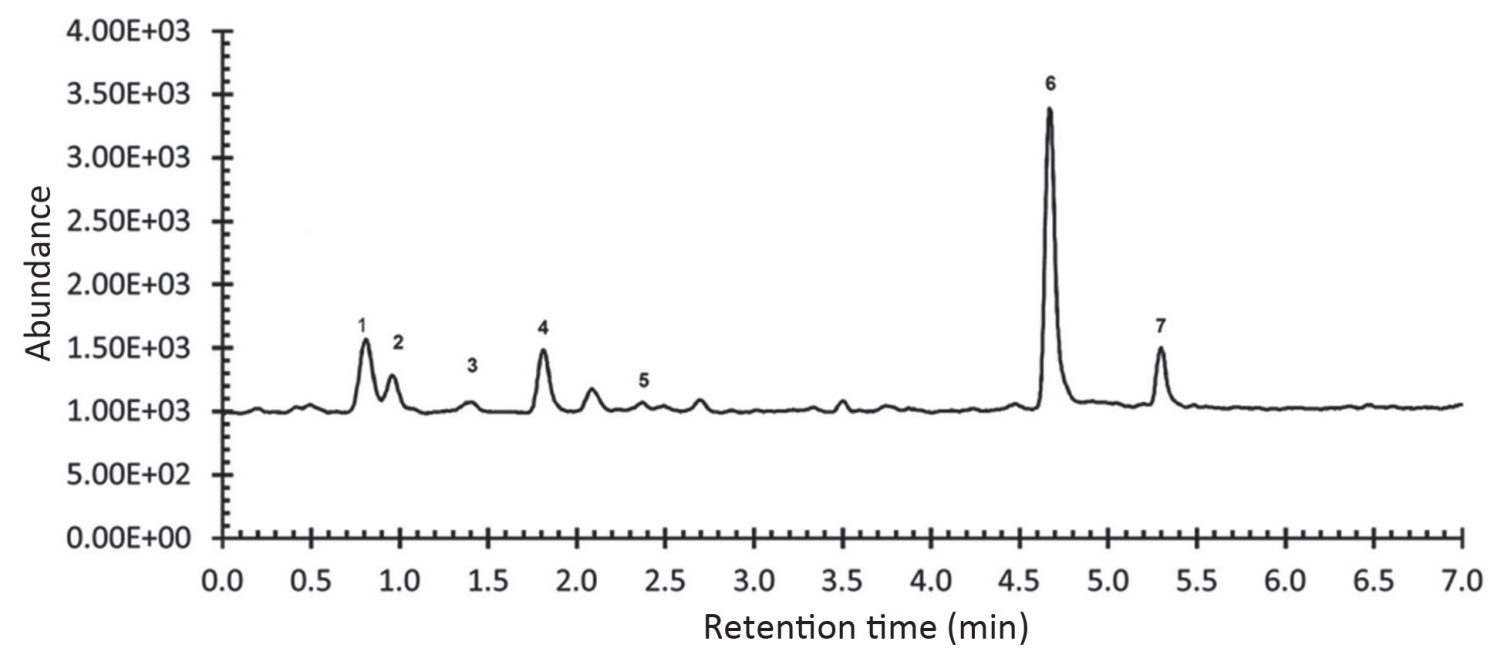

FIGURE 1 - UHPLC/MS chromatogram of $V$. litoralis crude extract: 1-chlorogenic acid; 2-vanillic acid; 3-caffeic acid; 4-p-coumaric acid; 5-ferulic acid; 6-luteolin; 7-apigenin. 
TABLE I - Compounds of $V$. litoralis crude extract identified and quantified by Ultra High Performance Liquid chromatography coupled with Mass Spectrometry in Tandem (UHPLC-MS/MS)

\begin{tabular}{lccccc}
\hline Peak & $\begin{array}{c}\text { Retention } \\
\text { time (min) }\end{array}$ & $\begin{array}{c}\text { Quantification } \\
\text { transition }\end{array}$ & $\begin{array}{c}\text { Confirmation } \\
\text { transition }\end{array}$ & Compound & $\begin{array}{c}\text { Concentration } \\
\boldsymbol{\mu g ~ g}^{-1} \text { of plant }\end{array}$ \\
\hline 1 & $0.61-0.94$ & $353.1>191.1(5)$ & - & chlorogenic acid & $1484.5 \pm 24.2$ \\
2 & $0.87-1.13$ & $167.0>152.2(10)$ & $167.0>152.2$ & vanillic acid & $18.1 \pm 3.0$ \\
3 & $0.89-1.10$ & $179.0>135.1(10)$ & - & caffeic acid & $41.8 \pm 2.9$ \\
4 & $1.70-2.01$ & $163.0>119.1(9)$ & - & $p$-coumaric acid & $33.1 \pm 0.4$ \\
5 & $2.40-2.66$ & $193.1>134.1(9)$ & $193.1>178.1(7)$ & ferulic acid & $10.7 \pm 0.6$ \\
6 & $4.37-4.97$ & $285.0>133.2(27)$ & $285.0>151.1(27)$ & luteolin & $177.7 \pm 4.7$ \\
7 & $5.19-5.53$ & $269.0>117.1(29)$ & $269.0>149.0(20)$ & apigenin & $37.9 \pm 0.8$ \\
8 & $4.26-4.54$ & $147.0>103.2(5)$ & $147.0>77.1(15)$ & trans-cinnamic acid & $<$ ILOQ \\
9 & $4.37-4.96$ & $301.0>151.1(17)$ & $301.0>179.0(15)$ & quercetin & $<$ ILOQ \\
\hline
\end{tabular}

\section{Anti-inflammatory activity}

Treatment of animals during seven consecutive days with the crude extract and the acetate fraction of $V$. litoralis induced a significant reduction of the granuloma weight as shown in Figure 2. Animals treated with nimesulide showed the granuloma weight of $0.11 \pm 0.01 \mathrm{~g}$. The hydroalcoholic extract and the acetate fraction resulted in the granuloma weight of $0.12 \pm 0.03 \mathrm{~g}$ and $0.13 \pm 0.02 \mathrm{~g}$, respectively, comparable to the reference substance. The ethyl acetate fraction was selected for the analysis based on the literature, which shows that it contains higher concentrations of phenolic compounds (Rosa et al., 2010; Silva et al., 2012).

Administration of the crude extract and the acetate fraction of $V$. litoralis, together with nimesulide, was compared to the control group of propylene glycol/water, demonstrating that there was a significant difference in lipase and alanine aminotransferase (ALT) between groups (Table II). Hemograms and leukograms of the animals

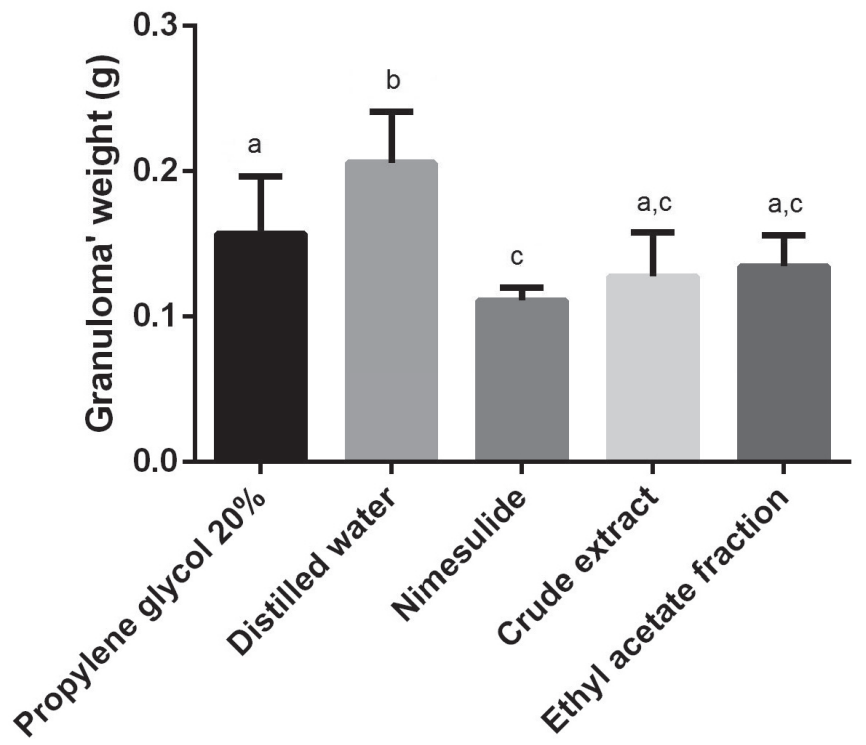

FIGURE 2 - Effect of daily oral administration of extracts for 7 days on the granulomatous tissue formation. The bar represents the mean \pm S.D. of six rats. Means identified by the same letter do not differ statistically.

TABLE II - Liver, kidney and pancreas damage markers obtained from animal serum after treatment through the administration of the crude extract and the ethyl acetate fraction of $V$. litoralis

\begin{tabular}{lccccc}
\hline & PR & $\mathrm{H}_{2} \mathrm{O}$ & $\mathrm{N}$ & $\mathrm{EB}$ & FA \\
\hline AST (U/L) & $236.3 \pm 38.99^{\mathrm{a}}$ & $271.8 \pm 67.53^{\mathrm{a}}$ & $247.5 \pm 75.40^{\mathrm{a}}$ & $239.3 \pm 57.93^{\mathrm{a}}$ & $241.5 \pm 53.18^{\mathrm{a}}$ \\
ALT (U/L) & $54.84 \pm 9.10^{\mathrm{c}}$ & $43.40 \pm 13.13^{\mathrm{a}, \mathrm{c}}$ & $51.82 \pm 6.30^{\mathrm{b}, \mathrm{c}}$ & $37.98 \pm 5.32^{\mathrm{a}, \mathrm{b}}$ & $32.88 \pm 8.67^{\mathrm{a}}$ \\
Urea (mg/dL) & $51.48 \pm 9.97^{\mathrm{a}}$ & $57.80 \pm 14.30^{\mathrm{a}}$ & $53.57 \pm 7.96^{\mathrm{a}}$ & $49.90 \pm 11.12^{\mathrm{a}}$ & $50.61 \pm 7.83^{\mathrm{a}}$ \\
Amylase (U/L) & $1305 \pm 195.6^{\mathrm{a}}$ & $1306 \pm 279.5^{\mathrm{a}}$ & $1084 \pm 214.4^{\mathrm{a}}$ & $1490 \pm 347.1^{\mathrm{a}}$ & $1295 \pm 190.1^{\mathrm{a}}$ \\
Lipase (U/L) & $8.80 \pm 1.30^{\mathrm{a}, \mathrm{c}}$ & $9.40 \pm 1.82^{\mathrm{a}, \mathrm{c}}$ & $5.80 \pm 2.16^{\mathrm{a}}$ & $12.20 \pm 2.28^{\mathrm{b}, \mathrm{c}}$ & $15.00 \pm 4.95^{\mathrm{b}}$ \\
Creatinine (mg/dL) & $0.55 \pm 0.04^{\mathrm{a}}$ & $0.54 \pm 0.06^{\mathrm{a}}$ & $0.56 \pm 0.03^{\mathrm{a}}$ & $0.55 \pm 0.06^{\mathrm{a}}$ & $0.58 \pm 0.09^{\mathrm{a}}$ \\
\hline
\end{tabular}

PR: animals treated with propylene glycol $20 \% ; \mathrm{H}_{2} \mathrm{O}$ : animals treated with distilled water; $\mathrm{N}$ : animals treated with nimesulide; EB: animals treated with crude extract; FA: animals treated with acetate fraction. Data represent mean and standard deviation. Means followed by the same letter do not differ statistically (horizontal). ANOVA was applied followed by Tukey Test $(\mathrm{p}<0.05)$. 
showed no significant differences between the groups with and without treatment.

\section{DISCUSSION}

Data obtained in the literature reveal that many plant species possessing analgesic and antipyretic activities are able to interfere with the proliferative components present in the inflammatory process, thus effectively inhibiting the granuloma formation (Xu et al., 2014; Kumar et al., 2016; Ghosh et al., 2013). Since the aerial parts of Verbena litoralis are traditionally employed in the treatment of inflammation, fever and pain (Cáceres, 1999; Li et al., 2003; Castro-Gamboa, Castro, 2004), this study was performed in order to assess the potential antiinflammatory activity of this plant through the inhibition of granulomatous tissue formation.

In this study, both the crude extract and the ethyl acetate fraction showed significant inhibitory activity in the formation of the granulomatous tissue, indicating a potential anti-inflammatory action of Verbena litoralis. This activity can be related to the chemical compounds identified in the phytochemical analysis (UHPLC/MS). Chlorogenic acid, a naturally occurring phenolic acid, exerts a positive impact on the organism due to its wide range of biological actions such as antioxidant, antibacterial, hypoglycemic, anti-inflammatory, antifungal and anticancer properties (Kujawa, Mikolajczyk, Kleszczynska, 2015). A recent study realized by Shin et al. (2015) showed the effects of chlorogenic acid on inflammation (colitis) induced by dextran sodium sulfate (DSS) in mice. It was observed that the supplementation with chlorogenic acid orally administered by gavage was able to cause an attenuation of the symptoms related to the inflammatory process. Another compound identified in Verbena litoralis and with proven anti-inflammatory activity is the caffeic acid. Zhang et al. (2014) reported its anti-inflammatory activity in mice that had a contact dermatitis (edema and local inflammation) induced by the application of 12-o-tetradecanoyl-phorbol-13-acetate (TPA) to the ears. The topical application of caffeic acid significantly reduced the ear thickening, thus indicating its therapeutic effect. Among the phenolic compounds found in the crude extract of $V$. litoralis, we can emphasize luteolin. Luteolin is reported to exert its anti-inflammatory activity by inhibiting COX-2, leukotrienes and arachidonic acid enzymes. When testing cotton pellet-induced granuloma, Gosh et al. (2013) found that luteolin significantly decreased the weight of the cotton pellet compared to indomethacin. Another important phenolic compound identified in $V$. litoralis was apigenin.
Chen et al. (2017) in their studies found that levels of IL-2, IL-4 and IL-10 increased significantly after isoflurane exposure in rats and treatment with $100 \mathrm{mg} / \mathrm{kg}$ of apigenin suppressed isoflurane-induced neuroinflammation.

The hepato- and nephrotoxicities of plant extracts are frequently accessed by the dosages of AST, ALT, BUN and CRE, respectively (Brondani et al., 2017). Moreover, lipase and amylase determinations are used as markers of pancreatic injuries (Steinberg et al., 2017). In this study, although lipase had an increase in crude extract and ethyl acetate fraction, Muniraj et al. (2015) indicate that, for a diagnosis of acute pancreatitis, the amylase and/or lipase must be three times higher than the physiological limit. Therefore, the elevation in this parameter may have occurred as a reflex of a non-pancreatic disease, indicating that both the crude extract and the ethyl acetate fraction may affect the metabolism and excretion of lipase from the peripheral kidney or tissues, causing its increase in blood (Steinberg et al., 2017).

Moreover, the alanine aminotransferase (ALT) enzyme was significantly decreased in the groups treated with the crude extract and the ethyl acetate fraction. It is well known that ALT is primarily limited to the hepatocyte cytosol and considered a highly sensitive indicator of hepatocellular damage. Within certain limits, this parameter may also provide a quantitative rate of damage to the liver (Al-Habori et al., 2002). The reduction of ALT suggests that $V$. litoralis has some hepatoprotective properties that may be related to its chemical composition identified by UHPLC/MS, since luteolin, chlorogenic acid, caffeic acid and apigenin have already been proved to possess such activity. Corroborating with our findings, other studies have also reported similar hepatoprotective effects of plants (Brondani et al., 2017; Adewale et al., 2016; Pereira, Barros, Ferreira, 2016).

\section{CONCLUSION}

The flavonoids identified in $V$. litoralis are of great importance since they were found for the first time in the plant and anti-inflammatory action was attributed mainly to compounds chlorogenic acid, caffeic acid, luteolin and apigenin. As demonstrated, treatment with crude extract and acetate fraction inhibited the formation of granulomatous tissue with no evidence of damage to the liver, kidneys and pancreas.

\section{ACKNOWLEDGMENTS}

The authors thank Bioclin - Quibasa Química Básica (Belo Horizonte - MG, Brazil) for the donation 
of commercial kits for biochemical and hematological analyzes of blood.

\section{REFERENCES}

Adewale OBA, Onasanya A, Anadozie SO, Abu MF, Akintan IA, Ogbole CJ, et al. Evaluation of acute and subacute toxicity of aqueous extract of Crassocephalum rubens leaves in rats. J Ethnopharmacol. 2016;188(21):153-158.

Al-Habori M, Al-Aghbari A, Al-Mamary M, Baker M. Toxicological evaluation of Catha edulis leaves: a long term feeding experiment in animals. J Ethnopharmacol. 2002;83(3):209-217.

Bailey PJ, Sturm A, Lopez-Ramos B. Biochemical study of the cotton pellets granuloma in rats: Effects of dexamethasone and indomethacin. Biochem Pharmacol. 1982;31(7):1213-1218.

Barroso GM. Sistemática de angiospermas do Brasil. Viçosa, Minas Gerais: Imprensa Universitária; 2004.

Brandão HN, David JP, Couto RD, Nascimento JAP, David JM. Química e farmacologia de quimioterápicos antineoplásicos derivados de plantas. Quím Nova. 2010;33(6):1359-1369.

Brondani JC, Reginato FZ, Brum ES, Vencato MS, Lhamas $\mathrm{CL}$, Viana $\mathrm{C}$, et al. Evaluation of acute and subacute toxicity of hydroethanolic extract of Dolichandra unguis-cati L. leaves in rats. J Ethnopharmacol. 2017;202(18):147-153.

Cáceres A. Plantas de Uso Medicinal em Guatemala. San Carlos, Guatemala: Editorial Universitária; 1999.

Castro-Gamboa I, Castro O. Iridoids from the aerial parts of Verbena litoralis (Verbenaceae). Phytochem. 2004;65(16):23692372.

Chen L, Xie W, Xie W, Zhuang W, Jiang C, Liu N. Apigenin attenuates isoflurane-induced cognitive dysfunction via epigenetic regulation and neuroinflammation in aged rats. Arch Gerontol Geriatr. 2017;73(7):29-36.

Dalmora MEA. Interação do piroxicam com microemulsão catiônica e $\beta$-ciclodextrina: Formulação in vitro e avaliação biológica. [dissertação]. Santa Maria: Universidade Federal de Santa Maria, Departamento de Farmácia Industrial; 1996.

Dunne FJ. The natural health service: natural does not mean safe. Adv Psychiatr Treat. 2009;15(1):49-56.
Faccin H, Viana C, Nascimento PC, Bohrer D, Carvalho LM. Study of ion suppression for phenolic compounds in medicinal plant extracts using liquid chromatography-electrospray tandem mass spectrometry. J Chromatogr. 2016;1427(4):111-124.

Garlet TMB. Levantamento das plantas medicinais utilizadas no município de Cruz Alta, RS, Brasil. [dissertação]. Porto Alegre: Universidade Federal do Rio Grande do Sul, Programa de PósGraduação em Botânica; 2000.

Ghasemzadeh A, Ghasemzadeh N. Flavonoids and phenolic acids: Role and biochemical activity in plants and human. J Med Plants Res. 2011;5(31):6697-6703.

Ghosh S, Chattopadhyay D, Mandal A, Kaity S, Samanta A. Bioactivity guided isolation of antiinflammatory, analgesic, and antipyretic constituents from the leaves of Pedilanthus tithymaloides (L.). Med Chem Res. 2013;22(9):4347-4359.

Jain NC. Essentials of veterinary hematology. Lea \& Febiger: Philadelphia; 1993.

Kujawa DB, Mikolajczyk SC, Kleszczynska H. Molecular mechanism of action of chlorogenic acid on erythrocyte and lipid membranes. Mol Membr Biol. 2015;32(2):1-9.

Kumar R, Gupta YK, Singh S, Raj A. Anti-inflammatory Effect of Picrorhiza kurroa in Experimental Models of Inflammation. Planta Med. 2016;82(16):1403-1409.

Li Y, Ishibashi M, Satake M, Chen X, Oshima Y, Ohizumi Y. Sterol and triterpenoid constituents of Verbena litoralis with NGF-potentiating activity. J Nat Prod. 2003;66(5):696-698.

Marodin SM. Plantas utilizadas como medicinais no município de Dom Pedro de Alcântara, Rio Grande do Sul. [tese]. Porto Alegre: Universidade Federal do Rio Grande do Sul; 2000.

Meier R, Schuler W, Desaulles PL. Unisc Acid: tumor inhibitor isolated from Lichens. Experim. 1975;31(6):625.

Muniraj T, Dang S, Pitchumoni CS. Pancreatitis or not? Elevated lipase and amylase in ICU patients. J Crit Care. 2015;30(6):1370-1375.

Pereira C, Barros L, Ferreira IC. Extraction, identification, fractionation and isolation of phenolic compounds in plants with hepatoprotective effects. J Sci Food Agric. 2016;96(4):10681084. 
Rosa EA, Silva BC, Silva FM, Tanaka CMA, Peralta RM, Oliveira CMA, et al. Flavonoides e atividade antioxidante em Palicourea rigida Kunth, Rubiaceae. Rev Bras Farmacogn. 2010;20(4):484-488.

Schalm OW. Veterinary Hematology. Philadelphia: Lea \& Febiger; 1970.

Sebold DF. Levantamento etnobotânico de plantas de uso medicinal no município de Campo Bom, Rio Grande do Sul, Brasil. [tese]. Porto Alegre: Universidade Federal do Rio Grande do Sul; 2003.

Seelinger G, Merfort I, Wolfle U, Schempp CM. Anticarcinogenic effects of the flavonoid luteolin. Molec. 2008;13(10):2628-2651.

Shin HS, Satsu H, Bae MJ, Zhao Z, Ogiwara H, Totsuka M, et al. Anti-inflammatory effect of chlorogenic acid on the IL-8 production in Caco-2 cells and the dextran sulphate sodiuminduced colitis symptoms in C57BL/6 mice. Food Chem. 2015;168:167-175.

Silva PS, Suzuki EY, Moreira AP, Raposo NRB, Alves TMA, Viccini LF. Stachytarpheta gesnerioides Cham.: chemical composition of hexane fraction and essential oil, antioxidant and antimicrobial activities. Blacpma. 2012;11(6):542-548.

Simões CMO, Schenkel EP, Mello JCP, Mentz LA, Petrovick PR. Farmacognosia do Produto Natural ao Medicamento. Porto Alegre: Artmed; 2017.
Souza TJT, Manfron MP, Zanetti GD, Hoelzel SCSM, Pagliarin VP. Análise Morfo-Histológica e Fitoquímica de Verbena litoralis Kunth. Acta Farm Bonaer. 2005;24(2):209-214.

Souza VC, Lorenzi H. Botânica Sistemática: guia ilustrado para identificação das famílias de Angiospermas da flora brasileira, baseado em APG II. Nova Odessa: Instituto Plantarum; 2005.

Steinberg WM, Rosenstock J, Wadden TA, Donsmark M, Jensen CB, Devries JH. Impact of Liraglutide on Amylase, Lipase, and Acute Pancreatitis in Participants With Overweight/ Obesity and Normoglycemia, Prediabetes, or Type 2 Diabetes: Secondary Analyses of Pooled Data From the SCALE Clinical Development Program. Diabetes Care. 2017;40(7):839-848.

Stockham SL, Scott MA. Fundamentos de Patologia Clínica Veterinária. Rio de Janeiro: Guanabara-Koogan; 2011.

Xu Q, Wang Y, Guo S, Shen Z, Wang Y, Yang L. Antiinflammatory and analgesic activity of aqueous extract of Flos populi. J Ethopharmacol. 2014;152(3):540-545.

Zhang M, Zhou J, Wang L, Li B, Guo J, Guan X, et al. Caffeic acid reduces cutaneous tumor necrosis factor alpha (TNF- $\alpha$ ), IL- 6 and IL- $1 \beta$ levels and ameliorates skin edema in acute and chronic model of cutaneous inflammation in mice. Biol Pharm Bull. 2014;37(3):347-354.

Received for publication on $05^{\text {th }}$ August 2017 Accepted for publication on $04^{\text {th }}$ November 2018 